\title{
The potential role of safari hunting as a source of revenue for protected areas in the Congo Basin
}

\author{
David S. Wilkie and Julia F. Carpenter
}

\begin{abstract}
In sub-Saharan Africa conservation of biodiversity is increasingly predicated on finding ways to ensure that the economic value of maintaining a landscape in its 'natural' state meets or exceeds the expected returns from converting the area to an alternative land use, such as agriculture. 'Wildlands' in Africa must generate, directly or from donor contributions, funds sufficient to cover both the operating costs of conservation, and the opportunity costs of forgoing other forms of resource use. Government and donor investments currently meet less than 30 per cent of the estimated recurring costs required to manage the protected-area network within central African countries effectively, and cover none of the growing opportunity costs incurred to maintain protected areas. Unfortunately, few additional sources of funding are available.
\end{abstract}

\section{Introduction}

The protected-area network in the six nations of central Africa (Republic of Cameroon, Central African Republic, Republic of Congo, Democratic Republic of Congo, Equatorial Guinea and Gabon) covers approximately 6 per cent of the landscape. As discussed by Wilkie \& Carpenter (1999) there is a large discrepancy between income generated in the protected areas and the costs of maintaining them. Furthermore, the revenue lost by maintaining these areas as wildlife sanctuaries rather than using them for other purposes adds to the overall costs incurred. Civil unrest, isolation and poor infrastructure in the region effectively preclude tourism as a significant source of revenue, except where gorillas have been habituated (Wilkie \& Carpenter, 1999). However, safari hunters may not be discouraged by difficult conditions, and, as a result, trophy hunting may be able to generate rates of return sufficient to warrant investment in hunting infrastructure.

David S. Wilkie (corresponding author) 18 Clark Lane, Waltham, MA 02451-1823, USA. Tel.: + 1781894 9605; fax: + 1617552 0523; e-mail: dwilkie@msn.com

Julia Carpenter 68 High Street, Winchester, MA 01890, USA. Tel. + 1781729 6078; e-mail: jcarpent1@ix.netcom.com

Received 31 July 1998. Accepted 13 May 1999
Tourism is only economically viable where charismatic species exist in 'safe' areas that are not more than a few hours drive in a $4 \times 4$ vehicle from an international airport-ostensibly excluding tourism from most of central Africa. In contrast, a review of available information suggests that safari hunting could offer a significant and sustainable source of financing to offset some of the costs of maintaining protected areas in central Africa. However, better quantitative data are needed to assess whether trophy hunting is both ecologically sustainable and economically competitive over the long term relative to other land uses.

Keywords Congo, conservation, protected areas, safari-hunting, wildlife.

\section{Trophy hunting in Africa}

Trophy or safari hunting has a long history in Africa. During the early phases of the colonial era, trophy hunting was used as a means to finance colonization and resulted in the local extinction of elephant, rhinoceros and other trophy species (for scientific names see Appendix 1) from much of southern and west Africa (Mackenzie, 1987). In fact, many protected areas in Africa were established in order to preserve the few remaining populations of trophy animals that had escaped the white-hunters (Mackenzie, 1987).

More recently, safari hunting has been repainted as a way to make wildlife conservation pay for itself (Kiss, 1990; Elkan, 1994; Kock, 1995; WCS, 1996; Lewis \& Alpert, 1997). While others have warned of the dangers of commercializing wildlife use (Geist, 1988; Freese, 1997), they have not disputed that the economic value of hunting African wildlife is substantial. Hunters, primarily from north America and Europe, are willing to pay $\$ U S 14,000-60,000$ + for a 10-21-day safari to hunt elephant, buffalo, lions, eland and other trophy species (Table 1). If taxed appropriately, safari hunting has the potential to generate substantial revenues for protectedarea management (DeGeorges, 1994).

There is considerable evidence showing that in the dry savannah landscapes typical of southern Africa, economic returns from wildlife ranching (live animal sales and safari hunting) are often greater than other 
land uses, such as cattle ranching (Cumming, 1991; Taylor, 1991; Kreuter \& Workman, 1994; Bojo, 1996; Hosking, 1996; Crowe et al., 1997) or timber harvesting (Campbell et al., 1996). In contrast, in medium- to highrainfall savannahs, domestic ungulates are more productive than wild species, and thus ranching is a more viable land use in these areas (MacNab, 1991). In dry savannahs, many ranchers in Botswana, Namibia, South Africa and Zimbabwe now include safari hunting as a primary source of revenue on lands considered uneconomic for cattle raising. A study by Price Waterhouse estimated that ranch-based hunting in Zimbabwe can generate revenues of $\$ \mathrm{US} 800 / \mathrm{sq} \mathrm{km}$ and a return on investment of 10 per cent (Leader-Williams et al., 1996).

The CAMPFIRE (Communal Areas Management Programme for Indigenous Resources) and ADMADE (Aministrative Management Design program for game management areas in Zambia) programmes in Zimbabwe and Zambia are using safari hunting to conserve wildlife and generate income for local communities (Balakrishnan \& Ndhlovu, 1992; Child, 1996a,b; Lewis \& Alpert, 1997). These programmes are considered successful relative to other conservation and development options, and have encouraged other nations to adopt similar approaches (Hennig, 1987; Jones, 1995; Barnes \& de Jager, 1996; Leader-Williams et al., 1996). In 1992-93 Tanzania received \$US3.6 million in trophy fees for 18 elephants, 222 lions, 214 leopards, 736 buffaloes, 459 zebras, and 5385 antelopes and other species, and the safari hunting industry generated almost \$US14 million in gross revenues (Leader-Williams et al., 1996). In Zimbabwe in 1990 trophy fees generated almost \$US4 million from 134 elephants, 503 buffaloes, 182 leopards and 7860 other species (Leader-Williams et al., 1996). In Namibia in 1993, 2063 national and international trophy hunters killed 8011 animals, generating over \$US6 million in revenues, of which \$US2.8 million was from trophy fees (Ashley et al., 1994). If managed well (i.e. revenues shared with local communities and a sufficient portion invested in resource management), trophy hunting appears to be able to attain the twin goals of wildlife conservation and economic development (Child et al., 1997; National Parks and Wildlife Service, 1998).

\section{Safari hunting in the Congo Basin}

There are no published accounts and few unpublished sources of information about the safari hunting industry in the Congo Basin. In addition, safari hunting companies are disinclined to discuss their operations and profitability. What little information exists is on Cameroon (DeGeorges, 1994; Elkan, 1994; WCS, 1996) and the Republic of Congo (WCS, 1998).

\section{Cameroon}

European and North American hunters have been trophy hunting in Cameroon for more than 20 years. In

Table 1 Relative prices (\$US) for 14-day trophy hunting safari in six countries in Africa

\begin{tabular}{|c|c|c|c|c|c|c|c|}
\hline & Tanzania & Benin & Cameroon & $\begin{array}{l}\text { Central African } \\
\text { Republic }\end{array}$ & South Africa & Zimbabwe & $\begin{array}{l}\text { Cameroon } \\
\text { forest }\end{array}$ \\
\hline a. Airfare (US-site return) & 2000 & 2500 & 2800 & 2800 & 1800 & 1800 & 2800 \\
\hline $\begin{array}{l}\text { b. Hunting licences and } \\
\text { fees }\end{array}$ & 2100 & - & 800 & 818 & - & - & 800 \\
\hline c. Trophy shipping & 1200 & 500 & 800 & 1000 & 1000 & 1000 & 800 \\
\hline $\begin{array}{l}\text { d. Community } \\
\text { development fee }\end{array}$ & 62 & - & - & 272 & - & - & - \\
\hline $\begin{array}{l}\text { e. Fee for average 14-day } \\
\text { safari }\end{array}$ & 17,500 & 15,000 & 18,600 & 19,000 & 4200 & 12,950 & 25,000 \\
\hline f. Average trophy fees & 1230 & 786 & 3274 & 2717 & 6900 & 3000 & 3274 \\
\hline $\begin{array}{l}\text { g. Average trophy }+ \\
\text { elephant }\end{array}$ & 5230 & 786 & 4911 & 2717 & 6900 & 13,000 & 4911 \\
\hline \multicolumn{8}{|l|}{ Cost to hunter } \\
\hline $\begin{array}{l}(\mathrm{a}+\mathrm{b}+\mathrm{c}+\mathrm{d}+\mathrm{e}+\mathrm{f}) \\
\text { Total }+ \text { elephant }\end{array}$ & 24,092 & 18,786 & 26,274 & 26,607 & 13,900 & 18,750 & 32,674 \\
\hline$(a+b+c+d+e+g)$ & 28,092 & 18,786 & 27,911 & 26,607 & 13,900 & 28,750 & 34,311 \\
\hline
\end{tabular}

Sources: http:/www.fauna-safari-club.com; http://www.huntingmall.com; http://www.imarkcompany.com; http:/www.are.org; http:// www.huntinfo.com; Sporting International, Inc.; Brooke Chilvers-Haut Chinko Safaris. Appendix 1 shows a list of trophy fees for safari hunting nations in sub-Saharan Africa.

N.B. Some nations allow elephant hunting only during 21-day safaris. Elephant hunting is not permitted in Benin, Central African Republic and South Africa. To allow comparison of trophy fees across nations, average trophy fee is based on one individual of each of the following species: bongo, buffalo, bushpig, waterbuck, duiker, kob. 
1994 direct fees from trophy hunting generated over $\$$ US750,000 in revenues for the government (Elkan, 1994), and the multiplier effect may double the total economic benefit. Although 30 per cent of safari hunting revenues should, by law, be placed in a special conservation fund to pay for game surveys, anti-poaching and community development activities (DeGeorges, 1994), records of deposits into the fund could not be found, and the Ministry of Environment and Forests (MINEF) staff have neither vehicles nor fuel with which to monitor safari-hunting operations.

In the northern province hunting zones, which vary in size from 190 to $1608 \mathrm{sq} \mathrm{km}$, have been established by MINEF in collaboration with the wildlife management school at Garoua (DeGeorges, 1994). Hunting areas in the Lobéké region of the eastern province have no clearly defined boundaries, and MINEF is apparently unaware of the actual location of any safari hunting camp (DeGeorges, 1994).

Trophy hunters must purchase a hunting permit (\$US258), fiscal stamp (\$US237), safari fee (\$US28/day), and trophy taxes for all animals killed (Elkan, 1994). In 1994 hunters were allowed to kill two animals in MINEF category 1 (elephant, bongo, buffalo, eland, roan antelope, lion and hippopotamus) and four from category 2 (including bay duiker, yellow-backed duiker, giant forest hog, waterbuck, bushbuck and hartebeest). This $2+4$ limit is now restricted to 12 -day hunting safaris. Hunters on 18-day safaris can shoot $4+8$ animals. Trophy taxes vary for each species, as do quoted prices. For example the trophy fee for an elephant is quoted to be \$US473 (Elkan, 1994), \$US1760 (M. Eaton, pers. comm.) or \$US1637 (Cameroon safari hunting company), suggesting that either MINEF pricing policies are ambiguous or that safari companies are profiting from advertising trophy fees that are higher than those set by the state.

In 1994 four hunting guides were bringing clients to the Lobéké region, although two of these had the majority of clients (Elkan, 1994). In addition, 15 independent, expatriate hunters organized hunts in areas outside safari hunting concessions. Most safari hunting companies are present in the Lobéké region only during the hunting season (December-June), thus they are relatively ineffective in controlling poaching. Only one safari hunting company maintains a year-round presence and makes efforts to protect its hunting zone (Elkan, 1994). The unwillingness of safari companies to invest in antipoaching efforts during off-season months may reflect: (a) uncertainty over their renewed access to a given concession area for the next hunting season; (b) that 'poaching' is not in direct competition for wildlife because market hunters predominantly exploit small duikers and primates that are not sought by safari hunters; and (c) that the costs of protection are not rewarded by increased trophy hunting revenues. Lastly, all safari companies in the forest rely on logging concession roads for access, and to spot sign of game for their clients. Because logging is highly selective and constitutes a wave of old-growth mining sweeping across the landscape, logging roads in the region are relatively transient. Consequently, long-term access to the forest within hunting concessions may require professional hunters to pay for road maintenance, thus altering the economic viability of safari hunting.

Bongo and elephant are the principal trophy attractions in the Lobéké region. However, safari hunting companies advertising in the USA note that, although elephants are relatively abundant in northern Cameroon (Waza National Park is even considered overpopulated), trophy elephants are of average quality compared with Safari Club International (SCI) records, indicating that the big-tuskers have already been hunted out (DeGeorges, 1994).

Between 1988 and 1994 an average of 15 bongo, 13 elephants, 4 buffaloes, 3 sitatunga and 4 giant forest hogs were killed each year by safari hunters in the Boumba and Ngoko Departments of the eastern province in Cameroon (Elkan, 1994). Under the regulations of the Convention on International Trade in Endangered Species of Wild Fauna and Flora (CITES), the tusks from 80 elephants may be exported per year from Cameroon-30 from the northern province and 50 from the southern, central and eastern provinces. In 1993-94 safari hunters killed only 10 elephants, all in the eastern province. With elephant populations in the eastern province estimated at 16,875 (70 per cent of all elephants in Cameroon), even if the total quota of 80 elephants were taken from this province the killing rate would still be less than the maximum 0.75 per cent estimated to sustain trophy quality (DeGeorges, 1994). A preliminary survey in the Lobéké region recorded bongo signs in 43 of $1000.5-\mathrm{km}$ transect segments (Elkan, 1994). Although this suggests that bongo may be relatively abundant, no density or production estimates are available from which to determine sustainable trophy hunting off-take rates. In 1997-98 bongo populations appeared to suffer a natural die-off in northern Congo and the Central African Republic as a result of nasal botfly infection (B. Lubin \& P. Elkan, pers. comm.). Natural die-offs are not uncommon among large mammal populations (Young, 1994), and are likely to reduce the number of trophy individuals available to hunters episodically.

Using 1997 trophy prices (see Appendix 1), safari hunting in the Boumba and Ngoko Departments would generate revenues of approximately $\$$ US50,000 per year for MINEF. DeGeorges (1994) indicated that wildfowl 
Table 2 Estimated revenues (\$US) generated by safari hunting in six countries in Africa

\begin{tabular}{|c|c|c|c|c|c|c|c|}
\hline & Tanzania & Benin & Cameroon & $\begin{array}{l}\text { Central African } \\
\text { Republic }\end{array}$ & South Africa & Zimbabwe & $\begin{array}{l}\text { Cameroon } \\
\text { forest }\end{array}$ \\
\hline Hunting season & Jul-Nov & Jan-Apr & Jan-Apr & Jan-Apr & Apr-Aug & May-Oct & Jan-Apr \\
\hline No. of 14-day periods & 10.93 & 8.57 & 8.57 & 8.57 & 10.93 & 13.14 & 8.57 \\
\hline \multicolumn{8}{|l|}{ Concessionaire profits } \\
\hline $\begin{array}{l}\text { Profit@30 per cent of } \\
\text { gross revenue per } \\
\text { 14-day safari }\end{array}$ & 5250 & 4500 & 5580 & 5700 & 1260 & 3885 & 7500 \\
\hline Full booking one hunter & 57,375 & 38,571 & 47,829 & 48,857 & 13,770 & 51,060 & 64,286 \\
\hline Full booking two hunters & 114,750 & 77,143 & 95,657 & 97,714 & 27,540 & 102,120 & 128,571 \\
\hline \multicolumn{8}{|c|}{ National revenue from one concession, non-elephant } \\
\hline Full booking one hunter & 37,064 & 6735 & 34,924 & 32,633 & 75,407 & 39,429 & 34,924 \\
\hline Full booking two hunters & 74,129 & 13,470 & 69,848 & 65,266 & 150,814 & 78,857 & 69,848 \\
\hline \multicolumn{8}{|c|}{ National revenue from one concession + elephant } \\
\hline Full booking one hunter & 80,799 & n.a. & 48,955 & n.a. & n.a. & 170,857 & 48,955 \\
\hline Full booking two hunters & 161,557 & n.a. & 97,911 & n.a. & n.a. & 341,714 & 97,911 \\
\hline \multicolumn{8}{|c|}{ Percentage of safari revenues retained in country } \\
\hline $\begin{array}{l}\text { Per cent captured } \\
\text { nationally }\end{array}$ & 14 & 4 & 16 & 14 & 50 & 16 & 12 \\
\hline $\begin{array}{l}\text { Per cent captured with } \\
\text { elephants }\end{array}$ & 26 & n.a. & 20 & n.a. & n.a. & 45 & 17 \\
\hline
\end{tabular}

hunting has considerable potential, and could augment the revenues generated by big-game hunting.

\section{Republic of Congo}

At present only one trophy hunting company (Congo Safaris, owned by Eric Stockenstroom) is active in Congo. However, the Haut Chinko safari company is negotiating to move its operations from the Central African Republic to Congo (B. Chilvers, pers. comm.). Congo Safaris has an exclusive contract to hunt in both the Kabo and Pokola logging concessions in northern Congo-a total area of $8704 \mathrm{sq} \mathrm{km}$. The Pokola contract issued in 1997 was for an initial 1-year pilot to be extended to 10 years. The company uses $1510 \mathrm{sq} \mathrm{km}$ centred on the border between the two concessions. Between 1997 and 1998 Congo Safaris gave \$US1200 to the Kabo school and health clinic as payment of a special trophy hunting tax designated to benefit local communities (WCS, 1998). No additional information on the cost of hunting with Congo Safaris, or the number of hunters that hunted within the Kabo or Pokola concessions is available.

\section{Estimated economic returns from safari hunting}

To assess the potential value of safari hunting as a source of revenue to offset the costs of protected-area management, we used prices from 14-day safaris adver- tised by safari hunting companies working in the region, and assumed a profit margin of 30 per cent of gross revenues. Tables 1 and 2 attempt to compare the relative prices of, and economic returns from, trophy hunting from several nations in sub-Saharan Africa.

Assuming that a safari hunting company was fully booked with one to two hunters per 14-day safari for the whole hunting season, national revenue from trophy fees from a single hunting concession could reach \$US150,000 per year without elephants, or \$US340,000 with elephants. In general, southern African countries capture up to 50 percent of the proceeds of safari hunting, whereas Congo Basin countries tend to have lower fees and consequently lower potential national revenues (\$US30,000-100,000).

The capacity for safari hunting to generate sustainable and substantial revenues will depend on: (a) the abundance of trophy animals, which determines the size of safari hunting concessions and the number of hunters that can exploit the resource sustainably; and (b) continuing high demand for African trophy animals by hunters. Child (1997) reports that in southern Africa animals are shot at the rate of c. 0.7/day on big-game safaris (i.e. those targeted at the big 'four': elephant, lion, leopard and buffalo), but that the rate increases to 1-1.5 when other species are included (Kiss, 1990; Appendix 4). As a result revenues from hunting can be maximized by combining high-value trophy species that raise the daily rate, with lesser species that increase the number of days spent hunting. 
We assume that $c$. $\$$ US35,000 in government revenues can be generated from each safari hunting company, given a fully booked safari season with one client hunting everything except elephant during each 14-day period. Thus, Elkan's (1994) reported total government revenues of $\$ U S 757,575$ per year from safari hunting would require that there were 21 fully booked safari concessions serving a total of 180 clients each year. This figure seems high given the scale of hunting reported for south-eastern Cameroon (Elkan, 1994), suggesting that either government revenue estimates are incorrect or demand for trophy hunting in Cameroon is stronger than reported. Safari Club International asserts that one-third of its core membership of 30,000 hunters travel to Africa to hunt at least once every 2 years-i.e. 5000 per year (Leader-Williams et al., 1996). Thus, Cameroon would have to attract only 4 per cent of SCI members travelling to Africa to maintain a revenue stream of $\$ \mathrm{US750,000}$ per year in trophy fees, which constitutes almost 40 per cent of the management costs of all protected areas in the country.

\section{Conclusions}

Trophy or recreational hunting is a multi-billion-dollar industry in Europe and the United States (Freese, 1996), and generates significant revenues in Africa. Given this proven willingness-to-pay, safari hunting has the potential to contribute significantly to the economies of 'wildlife-endowed' nations in Africa, both in direct and in multiplier terms.

In central Africa, the paucity of information on: (a) the number of safari hunters visiting the region; (b) the number of animals killed by safari hunters each year; and, (c) the revenues generated from safari hunting, leave governments, donors and international conservation NGOs uncertain about trophy hunting's potential role as a tool for financing biodiversity conservation in the region. At present it is unclear whether demand for safari hunting in the Congo Basin is sustainable given the high cost to hunters relative to other safari-hunting destinations, and the fact that North American hunters, unlike their European counterparts, are less interested in repeat safaris, being more concerned with adding new species to their trophy list (B. Lubin, pers. comm.). Given this, governments in the Congo Basin may be unable to raise trophy fees to levels comparable with other destinations, and safari hunting companies may need to find a constant stream of new clients if they are to maintain revenues from year to year. Furthermore, without better information on harvest rates and their impact on trophy species population densities over time, it is unclear whether safari hunting is ecologically sustainable.
Safari hunting has the potential to provide central African nations with a private sector tool for forest resource conservation. However, trophy hunting will attain this goal only if revenues generated from hunters are invested in managing the resource, regulating the industry, and offsetting local and national opportunity costs associated with maintaining wildlands. Currently, there is little evidence that this is happening.

Given the recurring and opportunity costs of maintaining protected areas, the conservation of biodiversity in the Congo Basin is increasingly predicated on finding ways to ensure that the economic value of maintaining a landscape in its 'natural' state meets or exceeds the expected returns from converting the area to an alternative land use such as agriculture. It is clear from this review of available information, that more information is needed if safari hunting is to be advocated as a sustainable source of revenue to offset the costs of maintaining protected areas. Governments, donors, conservation organizations and safari hunters must collaborate to: (a) generate convincing evidence to test the assertion that commercial consumptive use by safari hunters has an important role to play in the conservation of wildlife in the forests of the Congo Basin; and (b) promote safari hunting practices in the Congo Basin that result in the sustainable commercial consumptive use of wildlife.

\section{Acknowledgements}

Thanks to Lee White, Bryan Curran, Roger Fotso, Stuart Marks and Brooke Chilvers for commenting on the manuscript. Thanks to World Wildlife Fund-US and the Wildlife Conservation Society for access to unpublished reports. This study was supported in part by funding from the United States Agency for International Development CARPE (Central African Regional Program for the Environment) project.

\section{References}

Ashley, C., Barnes, J. \& Healy, T. (1994) Profits, Equity, Growth and Sustainability: The Potential Role of Wildlife Enterprises in Caprivi and other Communal Areas of Namibia. Research Discussion Paper No. 2. Ministry of Environment and Tourism, Windhoek, Namibia.

Balakrishnan, M. \& Ndhlovu, D.E. (1992) Wildlife utilization and local people: a case-study in the Upper Lupande Game Management Area, Zambia. Environmental Conservation, 19, 135-144.

Barnes, J.I. \& de Jager, J.L.V. (1996) Economic and financial incentives for wildlife use on private land in Namibia and the implications for policy. South African Journal of Wildlife Research, 26, 37-46. 
Bojo, J. (1996) The Economics of Wildlife: Case Studies from Ghana, Kenya, Namibia, and Zimbabwe. World Bank, Washington, DC.

Campbell, B., Butler, J.R.A., Mapaure, I., Vermeulen, S.J. \& Mashove, P. (1996) Elephant damage and safari hunting in Pterocarpus angolensis woodland in northwestern Matabeleland, Zimbabwe. African Journal of Ecology, 34, 380-388.

Child, B. (1996a) The practice and principles of community-based wildlife management in Zimbabwe: the CAMPFIRE programme. Biodiversity and Conservation, 5, 369-398.

Child, B. (1997) Conservation beyond Yellowstone: an economic framework for wildlife conservation. In African Wildife Policy Consultation: Final Report of the Consultation, pp. 55-61. Overseas Development Administration, Sunningdale Park, UK.

Child, B., Ward, S. \& Tavengwa, T. (1997) Zimbabwe's CAMPFIRE Programme: Natural Resource Management by the People. IUCN-ROSA, Harare.

Child, G. (1996b) The role of community-based wild resource management in Zimbabwe. Biodiversity and Conservation, 5, 355-367.

Crowe, T.M., Smith, B.S., Little, R.M. \& High, S.H. (1997) Sustainable utilization of game at Rooipoort estate, northern Cape province, South Africa. In Harvesting Wild Species: Implications for Biodiversity Conservation (ed. C. H. Freese), pp. 359-392. Johns Hopkins University Press, Baltimore.

Cumming, D.H.M. (1991) Developments in game ranching and wildlife utilisation in east and southern Africa. In Wildlife Production: Conservation and Sustainable Development (eds L. A. Renecker and R. J. Hudson), pp. 96-108. University of Alaska, Fairbanks.

DeGeorges, A. (1994) Preliminary Discussions Leading to Development of an Elephant Conservation Program between the Cameroonian Ministry of Environment and Forests and Safari Club International. Safari Club International, Tucson, USA.

Elkan, P.W. Jr (1994) A Preliminary Survey of Bongo Antelope and Assessment of Safari Hunting in the Lobéké region of southeastern Cameroon. Wildlife Conservation Society, Bronx.

Freese, C.H. (1996) The Commercial, Consumptive Use of Wild Species: Managing it for the Benefit of Biodiversity. World Wildlife Fund, Washington, DC.

Freese, C.H. (1997) Harvesting Wild Species: Implications for Biodiversity Conservation. Johns Hopkins University Press, Baltimore.

Geist, V. (1988) How markets for wildlife meat and parts, and the sale of hunting privileges, jeopardize wildlife conservation. Conservation Biology, 2, 15-26.

Hennig, R. (1987) The development of game and hunting management in South West Africa/Namibia. Zeitschrift fur Jagdwissenschaft, 33, 248-267.

Hosking, S. (1996) Official statistics on the income generated by the hunting industry in South Africa. South African Journal of Wildlife Research, 26, 103-106.

Jones, B.T.B. (1995) Wildlife Management, Utilization and Tourism in Communal Areas: Benefits to Communities and Improved Resource Management. Research Discussion Paper
Number 5. Ministry of Environment and Tourism, Windhoek, Namibia.

Kiss, A (ed.) (1990) Living with Wildlife: Wildlife Resource Management with Local Participation in Africa. Technical Paper No. 130. World Bank, Washington, DC.

Kock, R.A. (1995) Wildlife utilization: use it or lose ita Kenyan perspective. Biodiversity and Conservation, 4 , 241-256.

Kreuter, U.P. \& Workman, J.P. (1994) Costs of overstocking on cattle and wildlife ranches in Zimbabwe. Ecological Economics, 11, 237-248.

Leader-Williams, N., Kayera, J.A. \& Overton, G.L. (1996) Tourism Hunting in Tanzania. IUCN, Gland, Switzerland.

Lewis, D.M. \& Alpert, P. (1997) Trophy hunting and wildlife conservation in Zambia. Conservation Biology, 11, 59-68.

Mackenzie, J.M. (1987) Chivalry, social Darwinism and ritualised killing: the hunting ethos in Central Africa up to 1914. In Conservation in Africa: People, Policies and Practice (eds D. Anderson and R. Grove), pp. 41-61. Cambridge University Press, Cambridge, UK.

MacNab, J. (1991) Does game cropping serve conservation? A reexamination of the Africa data. Canadian Journal of Zoology, 69, 2283-2290.

National Parks and Wildlife Service (1998) Achieving ADMADE Sustainability: 4th Quarter 1998 Progress Report to USAID/Zambia. Ministry of Tourism, Nyamaluma, Zambia.

Taylor, R.D. (1991) Socio-economic aspects of meat production from impala harvested in Zimbabwean communal land. In Wildlife Production: Conservation and Sustainable Development (eds L. A. Renecker and R. J. Hudson), pp. 182-193. University of Alaska, Fairbanks.

\section{Biographical sketches}

David S. Wilkie, Adjunct Associate Professor, Boston College, is a wildlife ecologist with a post-doctoral anthropology specialization in human behavioural ecology. He has over 15 years of research experience in the socio-economic aspects of household-level natural resource use in central and west Africa, and in central and south America. His research in the Congo Basin has focused on: determining the local and regional impact of forager and farmer subsistence practices on forest plant and animal composition, distribution and abundance; and the household economic determinants of Efe hunter-gatherer adoption of agriculture into their suite of subsistence activities. Other research interests include: examining the impacts of trade and the commercialization of non-timber forest products on forest animal populations; the role that logging plays in promoting bushmeat markets; the income and price elasticities of demand for bushmeat; and the use of satellite imagery and aerial photography to model the location, extent and rate of land transformation within rain forests.

Julia F. Carpenter gained a BA in Geography from Boston University and an MA in Environmental Policy from Tufts University, USA. Her research interests have focused on looking at options for conserving biodiversity in developing countries and on studying the relationship between rural resource users and biodiversity conservation. 
WCS (1996) The Lobéké Forest, southeast Cameroon: Summary of Activities: 1988-95. Wildlife Conservation Society, Bronx.

WCS (1998) Congo Forest Conservation Project. Final report USAID grant number: 679-0008-G-00-1384-00. Wildlife Conservation Society, Bronx.
Wilkie, D.S. \& Carpenter, J.F. (1999). Can nature tourism help finance protected areas in the Congo Basin? Oryx 33, 332338.

Young, T.P. (1994) Natural die-offs of large mammals: implications for conservation. Conservation Biology, 8, 410-418.

Appendix 1: Trophy hunting fees/taxes (\$US) in a range of African nations in 1998

\begin{tabular}{|c|c|c|c|c|c|c|c|}
\hline Species scientific name & English name & Tanzania & Benin & Cameroon & $\begin{array}{l}\text { Central } \\
\text { African } \\
\text { Republic }\end{array}$ & $\begin{array}{l}\text { South } \\
\text { Africa }\end{array}$ & Zimbabwe \\
\hline Hylochoerus meinertzhageni & Giant forest hog & - & - & 164 & 655 & - & - \\
\hline Phacochoerus aethiopicus & Warthog & 320 & 82 & - & 164 & 250 & 200 \\
\hline Potamochoerus porcus & Bushpig & 190 & - & 164 & 164 & 300 & 200 \\
\hline Hippopotamus amphibius & Hippopotamus & 840 & - & 819 & - & - & 2500 \\
\hline Giraffa spp. & Giraffe & - & - & - & - & 1450 & 1000 \\
\hline Cephalophus callipygus & Peter's duiker & - & - & 82 & - & - & - \\
\hline Cephalophus monticola & Blue duiker & - & - & 82 & 98 & - & - \\
\hline Cephalophus nigrifrons & Black-fronted duiker & - & - & 82 & - & - & - \\
\hline Cephalophus rufilatus & Red-flanked duiker & - & - & 82 & 98 & - & - \\
\hline Cephalophus spp. & Duiker & 180 & 33 & 82 & 98 & 200 & 100 \\
\hline Cephalophus silvicultor & Yellow-backed duiker & - & - & 164 & 491 & - & - \\
\hline Ourebia ourebi & Oribi & - & 49 & 82 & 98 & - & - \\
\hline Raphicerus campestris & Steenbok & - & - & - & - & 200 & 200 \\
\hline Raphiceros melanotis & Grysbok & - & - & - & - & - & 200 \\
\hline Oreotragus oreotragus & Klipspringer & - & - & - & - & - & 300 \\
\hline Tragelaphus euryceros & Bongo & - & - & 1637 & 1637 & - & - \\
\hline Tragelaphus derbianus & Giant eland & - & - & 1637 & 1310 & - & - \\
\hline Tragelaphus spp. & Eland & 840 & & & & 1200 & 900 \\
\hline Tragelaphus angasi & Nyala & - & - & - & - & 2000 & - \\
\hline Tragelaphus imberbis & Lesser kudu & 1300 & - & - & - & 900 & 700 \\
\hline Tragelaphus scriptus & Bushbuck & 340 & 131 & 164 & 229 & 600 & 400 \\
\hline Tragelaphus spekii & Sitatunga & - & - & 327 & - & - & - \\
\hline Tragelaphus strepsiceros & Greater kudu & 1170 & - & - & - & - & - \\
\hline Hippotragus equinus & Roan antelope & - & 278 & 819 & 278 & - & - \\
\hline Hippotragus niger & Sable antelope & 1200 & - & - & - & 4500 & 1800 \\
\hline Oryx gazella & Gemsbok & - & - & - & - & 900 & - \\
\hline Kobus defassa & Waterbuck & 440 & 229 & 409 & 229 & 1000 & 1000 \\
\hline Kobus kob & Kob & - & 164 & 164 & 262 & - & - \\
\hline Redunca spp. & Reedbuck & 290 & 115 & 164 & 196 & - & - \\
\hline Alcelaphus lichtensteinii & $\begin{array}{l}\text { Lichtenstein's } \\
\text { hartebeest }\end{array}$ & 370 & - & - & - & - & - \\
\hline Alcelaphus spp. & Hartebeest & 320 & 246 & 327 & 262 & 700 & - \\
\hline Connochaetes taurinus & Wildebeest & - & - & - & - & 700 & 600 \\
\hline Aepycerus melampus & Impala & 240 & - & - & - & 280 & 150 \\
\hline Syncerus caffer & Buffalo & 600 & 393 & 819 & 327 & 5600 & 1800 \\
\hline Equus burchelli & Zebra & 590 & - & - & - & 700 & 700 \\
\hline Loxodonta africana & Elephant & 4000 & - & 1637 & - & - & 10,000 \\
\hline Canis spp. & Jackal & 150 & - & - & - & 50 & 50 \\
\hline Crocuta crocuta & Spotted hyaena & 190 & - & - & - & 450 & 250 \\
\hline Panthera leo & Lion & 2000 & 1310 & 1637 & 1310 & - & 3500 \\
\hline Panthera leo & Lioness & - & - & - & - & - & 1500 \\
\hline Panthera pardus & Leopard & 2000 & - & - & 1719 & - & 2800 \\
\hline Papio spp. & Baboon & 90 & 16 & - & - & 80 & 50 \\
\hline
\end{tabular}

